\title{
Olivet - ZAC du Larry, zone 1
}

$n^{\circ} 064466$

\section{Alain Mairesse}

\section{(2) OpenEdition}

Journals

Édition électronique

URL : http://journals.openedition.org/adlfi/14322

ISSN : 2114-0502

Éditeur

Ministère de la culture

Référence électronique

Alain Mairesse, "Olivet - ZAC du Larry, zone 1 », ADLFI. Archéologie de la France - Informations [En ligne], Centre, mis en ligne le 20 mars 2015, consulté le 20 avril 2019. URL : http:// journals.openedition.org/adlfi/14322

Ce document a été généré automatiquement le 20 avril 2019.

(C) Ministère de la Culture et de la Communication, CNRS 


\section{Olivet - ZAC du Larry, zone 1}

$n^{\circ} 064466$

\section{Alain Mairesse}

Lien Atlas (MCC) :

http://atlas.patrimoines.culture.fr/atlas/trunk/index.php?

ap_theme=DOM_2.01.02\&ap_bbox=1.850;47.832;1.933;47.880

1 Deux fosses et un fossé parcellaire (période moderne) ont été mis au jour.

\section{INDEX}

Index chronologique : Temps Modernes

Index géographique : Centre, Loiret (45), olivet

Mots-clés : fosse, fossé

operation Évaluation archéologique (EV) 